Yüzüncü Yil Üniversitesi
Tarim Bilimleri Dergisi

Araştırma Makalesi (Research Article)

\title{
Akdeniz ve Güneydoğu Anadolu Bölgeleri’nde Antepfıstığında Salkım ve Sürgün Yanıklık Hastalığı (Botryosphaeria dothidea)'nın Patojenik ve Moleküler Karakterizasyonu
}

\author{
Serap TOKER DEMIRAY ${ }^{* 1}$, Efkan AKÇALI ${ }^{2}$ \\ ${ }^{1,2}$ Tarım ve Orman Bakanlığı, Biyolojik Mücadele Araştırma Enstitüsü, 01321, Adana, Türkiye \\ ${ }^{1}$ https://orcid.org/0000-0001-5930-2992 ${ }^{2}$ https://orcid.org/0000-0002-5486-7502 \\ *Sorumlu yazar e-posta: serap.tokerdemiray@tarimorman.gov.tr
}

\section{Makale Bilgileri}

Geliș: 06.04.2020

Kabul: 09.07.2020

Online Yayinlanma 31.12.2020

DOI: 10.29133/yyutbd.715163

Anahtar kelimeler

Antepfistığ1,

Botryosphaeria dothidea,

Hastalık şiddeti,

Salkım ve sürgün yanıklığı.
Öz: Türkiye, y1lda yaklaşık 144 bin ton üretim ile dünyanın üçüncü büyük antepfıstığ 1 üreticisidir. Antepfıstığında tespit edilen fungal hastalıklardan biri de salkım ve sürgün yanıklığına neden olan Botryosphaeria dothidea'dır. Bu patojen son on yılda önemli ve yaygın endofitlerden biri olmuştur. Bu çalışma, 2015 ve 2016 yıllarında Akdeniz ve Güneydoğu Anadolu Bölgesi'nde yer alan Mersin, Gaziantep ve Kilis illerinde antepfıstığ $ı$ bahçelerinde salkım ve sürgün yanıklık hastalığına neden olan etmenin türünü, yaygınlığını ve şiddetini belirlemek amacıyla yapılmıştır. Çalışma sonucunda, salkım ve sürgün yanıklık hastalı̆̆ına neden olan etmen hem morfolojik hem de moleküler yöntemler kullanılarak tanılanmış ve Botryosphaeria dothidea olduğu belirlenmiştir. Survey çalışmalarında salkım ve sürgün yanıklık hastalı̆̆ının en yüksek ortalama yaygınlık oranı ve ortalama hastalık şiddeti sırasıyla, $\% 71.28$ ve $\% 2.90$ olarak Mersin ilinde tespit edilmiştir.

\section{Pathogenic and Molecular Characterization of Panicle and Shoot Blight Disease (Botryosphaeria dothidea) in Pistachio in the Mediterranean and Southeastern Anatolia Regions}

\section{Article Info \\ Received: 06.04.2020 \\ Accepted: 09.07.2020 \\ Online Published 31.12.2020 \\ DOI: 10.29133 /yyutbd.715163 \\ Keywords \\ Pistachio, \\ Botryosphaeria dothidea, \\ Disease severity, \\ Panicle and shoot blight.}

\begin{abstract}
Turkey is the third largest pistachio producer in the world with about 144 thousand tons per year. One of the detected fungal diseases of pistachio is Botryosphaeria dothidea causing panicle and shoot blight. This pathogen has been one of serious and widespread endophytes during the last decade. This study was carried out to determine the species of fungi causing panicle and shoot blight disease, prevalence and disease severity in pistachio orchards of Mersin, Gaziantep and Kilis in the Mediterranean and Southeastern Anatolia Region in 2015 and 2016. Results revealed that the fungus which caused panicle and shoot blight disease was diagnosed as Botryosphaeria dothidea using both morphological and molecular methods. In the survey, the highest mean prevalence rate and mean disease severity of panicle and shoot blight disease were detected in Mersin as $71.28 \%$ and $2.90 \%$, respectively.
\end{abstract}




\section{Giriş}

Sert kabuklu meyveler grubunda yer alan antepfistığı (Pistacia vera L.), sakız ağacıgiller (Anacardiaceae) familyasından yenebilen kabuklu bir meyvedir. Meyveleri taze ve kuru olarak iç ve dış pazarlarda her zaman alıcı bulmaktadır. Satış değerinin yüksek ve veriminin iyi olması nedeniyle üreticiler tarafından diğer ürünlere oranla daha çok tercih edilmektedir. 'Altınağacı' ya da 'Yeşilaltın' olarak adlandırılan antepfıstığı, ilk olarak Güneydoğu Anadolu Bölgesi’nde Gaziantep ilinde kültüre alınmıştır. Antepfıstığı, dünyada kuzey ve güney yarım kürelerinin $30-45^{\circ}$ enlemleri arasındaki uygun mikro klimalarda yetişmektedir (Anonim, 2018a). Antepfistığında görülen periyodisite nedeniyle üretim miktarları yıldan yıla değişmektedir. Bundan dolayı dünyadaki üretim miktarı, yıllık üretim ortalamaları baz alınarak değerlendirilmektedir (Tekin ve ark., 2001). İran, Amerika Birleşik Devletleri ve Türkiye dünyada önemli antepfıstığı üretimi yapan ülkelerdendir. Birleşmiş Milletler Gıda ve Tarım Örgütü (FAO) verilerine göre, Dünya'da 2018 yılında 1.451 bin ton antepfıstığı üretilmiş̧tir. Bu üretimin \% 37.99'u İran, \% 30.85'i ABD ve \% 16.54'ü ise Türkiye tarafindan sağlanmıştır (Anonim, 2018b). Bundan dolayı ülkemiz antepfıstığı üretiminde söz sahibi ülkelerden biridir. Ülkemizde antepfıstığı yetiştiriciliği yoğun olarak Güneydoğu Anadolu Bölgesi'nde Gaziantep, Şanlıurfa, Siirt, Adıyaman ve Kilis illerinde, Akdeniz Bölgesi'nde ise Mersin ili Silifke ilçesinde yapılmaktadır.

Dünyada antepfistığı tarımını etkileyen 69 farklı fungal hastalık etmeninin bulunduğu ve bunlardan 27'sinin ekonomik kayba neden olduğu belirlenmiştir (Anonim, 1997). Dünyada ve ülkemizde antepfistığ 1 kök, kökboğazı, gövde, sürgün, salkım ve meyvelerinde tespit edilip ekonomik kayba neden olan önemli fungal hastalıklardan bazıları, Verticillium solgunluğu etmeni (Verticillium dahlia Kleb.), Külleme hastalık etmeni (Phyllactinia angulata), Kök ve taç çürüklüğü etmeni (Phytophthora spp. ve Fusarium equiseti (Cardo) Sacc.), Stigmatomikoz nedeni (Nematospora coryli Peglion ve Aureobasidium pullulans (de Bary) G. Arnaud), Antepfıstığında karazenk hastalığı etmeni (Pseudocercospora pistacina (All.) Crous, Quadv. \& Sarpkaya), Salkım ve sürgün yanıklık hastalığ etmeni (Botryosphaeria dothidea (Moug.:Fr.) Ces \& De Not.), Çiç̧ek ve sürgün yanıklı̆̆1 etmeni (Botrytis cinerea), Alternaria geç yanıklık hastalığı etmeni (Alternaria spp.), Aspergillus yanıklı̆̆ etmeni (Aspergillus spp.) ve Geriye ölüm hastalığı etmeni (Neoscytalidium novaehollandiae)'dir.

Antepfistığı salkım ve sürgünlerinden izole edilen B. dothidea, 20 familyaya ait 34 cinsteki 50 bitki türünü hastalandıran havai kökenli bir fungus olup, yüksek sıcaklıkta $\left(26.6-30{ }^{\circ} \mathrm{C}\right)$ iyi gelişmekte ve böylece hastalık ilkbahardan yaza doğru artmaktadır (Ahimera ve ark., 2003). Hastalık ilk önce sürgünlerde, yapraklarda ve meyve saplarında 1-2 mm çapında siyah-yuvarlak lekeler şeklinde görülmekte, zamanla bulaşık sürgünlerdeki yapraklar solmakta ve zamanından önce dökülmektedir. Salkım enfeksiyonlarında ise, salkımın bir kısmı ya da tamamı kurumaktadır. İlk meyve enfeksiyonları yaz ortasında görülmekte ve bir meyvede başlayan enfeksiyon gelişerek meyve sapını ve sonuçta tüm meyve salkımının olduğu sürgünün kurumasına neden olmaktadır (Teviotdale ve ark., 2002). Etmen antepfıstığı bahçeleri içerisine yerleştikten sonra hastalıkla mücadele etmek zordur.

Salkım ve sürgün yanıklık hastalığı etmeni B. dothidea meyve sapları, mumyalaşmış meyveler ile kanserli salkım ve sürgünlerin kabuğu içerisinde piknit oluşturmaktadır. Piknitler, primer inokulum kaynağı olarak varlığını sürdürürken, 6 yıl canlı kalabilen konidileri ürettiği belirtilmekte (Ahimera ve ark., 2003) ve zarar verdiği üretim alanlarında önemli verim ve kalite kaybına neden olmaktadır. ABD’nin Butte ve Tehama bölgelerinde 1994-1999 yılları arasında yapılan beş yıllık survey çalışmasında antepfıstığı bahçelerinin \%23'ünün salkım ve sürgün yanıklık hastalığı ile bulaşık olduğu (Leonard ve Ashley, 2011), California'da özellikle 1998 yılında zarar verdiği bahçelerde verimi \%54 oranında azalttığı ve toplam üretim kaybının ise yaklaşık 20 milyon İngiliz sterlin olduğu bildirilmektedir (Anonim, 2009).

$\mathrm{Bu}$ çalışma, 2015 ve 2016 yıllarında Akdeniz ve Güneydoğu Anadolu Bölgelerinde antepfıstığında salkım ve sürgün yanıklık hastalığı (Botryosphaeria sp.)'nın patojenik ve moleküler karakterizasyonunu belirlemek amacıyla yapılmış ilk çalışmadır.

\section{Materyal ve Yöntem}

Çalışmanın materyalini antepfıstığı üretim alanlarından toplanan örneklerden izole edilen fungal izolatlar, patojenisite çalışmasında kullanılan Kırmızı çeşidi antepfıstığı meyveleri ve dört farklı gen bölgesine ait primer çiftleri oluşturmaktadır. 


\subsection{Antepfıstığında salkım ve sürgün yanıklık hastalığının yaygınlığı ve şiddetinin belirlenmesi}

Salkım ve sürgün yanıklık hastalığının Akdeniz bölgesinde Mersin ilinde, Güneydoğu Anadolu Bölgesinde ise Gaziantep ve Kilis illerindeki yaygınlığı ve şiddetini belirlemek amacıyla 2015 ve 2016 yılı ilkbahar ve yaz döneminde antepfıstığı bahçelerinde survey çalışmaları yürütülmüşstür.

Survey çalışmalarında, antepfıstığı üretim alanlarının tamamını temsil edecek şekilde tesadüfi olarak örnekleme yapılmış ve örnekleme metodu Erkılıç ve ark. (1999)'dan modifiye edilmiştir. Örneklemede bahçe büyüklüğ̈̈, 1-10 dekar arası ise 10 ağaç,11-20 dekar arası ise 20 ağaç, 20-50 dekara arası ise 30 ağaç ve 50 dekardan büyük ise 50 ağaç incelenmiştir. Hastalık şiddetini belirlemek amaciyla örnekleme yapılan her bir ağacın dört farklı yönünden boy hizası dallar üzerindeki sürgünlerde bulunan 20 salkımda sayım yapılmıştır (Ahimera ve ark., 2003). Survey esnasında hastalığın görüldüğü bahçeler bulaşı kabul edilip, incelenen bahçe sayısına oranlanarak hastalığın yaygınlık oranı hesaplanmıştır (Karman, 1971).

Hastalık şiddetini belirlemede 'The Horsfall-Barratt'1n 0-7 skalası (Horsfall ve Barratt, 1945) modifeye edilerek kullanılmıştır.

Salkım ve sürgün yanıklık hastalığının salkımda oluşturduğu belirtileri değerlendirmede kullanılan modifiye edilmiş Horsfall-Barratt'ın 0-7 skalası (Horsfall ve Barratt, 1945);

0 : Hastalıklı salkım oranı \% 0, 1: Hastalıklı salkım oranı \% 1-5, 2: Hastalıklı salkım oranı \% 624, 3: Hastalıklı salkım oranı \% 25-49, 4: Hastalıklı salkım oran1 \%50-74, 5: Hastalıklı salkım oranı \% 75-89, 6: Hastalıklı salkım oranı \% 90-99, 7: Hastalıklı salkım oranı \% 100.

Sayım sonucu belirlenen skala değerleri üzerinden indeks formülü (Karman, 1971)'ne göre hastalık şiddeti belirlenmiştir.

\section{2. İzolasyon çalışmaları}

Hastalık etmenine ait izolatları toplamak amacıyla; survey esnasında antepfıstığı bahçelerinde hastalıklı olduğu belirlenen sürgün ve salkımların yaklaşık \%20'si örnek olarak alınarak laboratuvara getirilmiş ve izolasyon çalışmaları yapılmıştır. Bu amaçla, örnekler küçük parçalar (3-5mm) şeklinde kesilmiş ve daha sonra \% 1'lik sodyum hipoklorit ( $\mathrm{NaOCl}$ ) solüsyonu içerisinde 3 dakika süre ile bekletildikten sonra 2 defa steril saf suda yıkanarak durulanmış ve steril kurutma kağıtları üzerinde kurutulmuştur. Yüzey sterilizasyonu yapılan dokular patates dekstroz agar (PDA , Merck, Darmstadt, Germany) besi ortamı içeren petri kaplarına aktarılmıştır. Daha sonra petriler $27{ }^{\circ} \mathrm{C}$ sıcaklıkta 21 gün inkübasyona bırakılmış ve gelişen fungal koloni tek spor yöntemi ile saflaştırılmıştır. Koloninin rengi, pigment oluşumu ve gelişme hızı gibi özellikler makroskobik olarak incelenmiştir. Mikroskobik olarak ise; hif özellikleri, eşeysiz spor oluşumu, sporların şekli, rengi, büyüklüğü, bölme sayısı, konidiofor özellikleri, eşeyli spor yapılarının varlı̆ğ incelenmiştir. Makroskobik ve mikroskobik özellikler göz önüne alınarak cins düzeyinde tanılanma yapılmıştır (Slippers ve ark., 2004). Morfolojik olarak tanılaması yapılan 25 adet izolat patojenisite ve moleküler teşhis çalışmalarında kullanmak üzere +4 ${ }^{\circ} \mathrm{C}$ 'de buzdolabında eğik agar ortamında muhafaza edilmiştir.

\subsection{Patojenisite çalışmaları}

Patojenisite çalışmasında, morfolojik olarak cins düzeyinde tanısı yapılmış ve $+4{ }^{\circ} \mathrm{C}$ 'de buzdolabında eğik agar ortamında muhafaza edilmiş 25 adet izolatın tamamı kullanılmıştır. Bu izolatlar PDA ortamına ekilerek $27^{\circ} \mathrm{C}$ 'de üç hafta süre ile geliştirilmiştir. Gelişimini tamamlayan kültürlerin üzerine steril saf su ilave edilmiş ve kazıma ile kültürün steril saf suya geçmesi sağlanmıştır. Süspansiyonda bulunan miselyal kalıntıları uzaklaştırmak amacıyla 2 kat tülbent yardımıyla süzülmüş ve spor yoğunluğu thoma lamı kullanılarak $1 \times 10^{5}$ spor/ml'ye ayarlanmıştır. Yüzey sterilizasyonunu sağlamak amacıyla her izolat için kullanılacak olan 3 adet sağliklı kırmızı çeşidi antepfıstığı meyve salkımı \% 70'lik etil alkolde 10 saniye bekletilmiş ve iki defa steril saf sudan geçirilip yüzey suyunun kurumas1 sonrası, $1 \times 10^{5} \mathrm{spor} / \mathrm{ml}$ yoğunluğundaki inokulum meyvelere püskürtme şeklinde uygulanmıştır. İnokulasyonu tamamlanan meyveler $27^{\circ} \mathrm{C}$ sıcaklıkta inkübasyona bırakılmıştır (Zhang ve ark., 2012). Kontrolde ise steril saf su uygulanmıştır. Meyvelerde hastalık şiddeti inkübasyonu takiben bir hafta sonra modifiye edilmiş Horsfall-Barratt'1n 0-7 skalası (Horsfall ve Barratt, 1945) kullanılarak belirlenmiştir. Hastalık belirtisi gösteren meyvelerden reizolasyon yapılmıştır. Aynı izolat 
elde edilenler, patojen olarak kabul edilmiş ve moleküler olarak türleri tepit edilmek üzere $+4{ }^{\circ} \mathrm{C}$ 'de buzdolabında eğik agar ortamında muhafaza edilmiştir.

\subsection{DNA izolasyonu ve PCR çalışmaları}

\subsubsection{DNA izolasyonu}

Tanısı yapılan ve PDA eğik ortamına alınarak buzdolabında (+4) muhafaza edilen kültürlerin türleri moleküler yöntemler kullanılarak belirlenmiştir. DNA izolasyon çalışmalarında Qiagen DNeasy Plant Mini Kit kullanılmış ve Camele ve ark. (2005)'in DNA izolasyonu için yaptığ protokol uygulanmiştır.

PDA eğik ortamı üzerinde geliştirilen saf kültürler PDA besi ortamı üzerine aktarılarak $25 \pm 1^{\circ} \mathrm{C}$ de, 12 saat aydınlık, 12 saat karanlık olacak şekilde 8 gün süre inkübasyona bırakılmıştır. İnkübasyon süresi sonunda geliştirilen yaklaşık $1 \mathrm{~g}$ fungal kitle bir pipet ucu yardımıyla agarın üst yüzeyinden kazınmış ve sıvı azot yardımı ile ezilmiş ve $0.1 \mathrm{~g}$ alınarak $1.5 \mathrm{ml}$ 'lik ependorf tüplere aktarılmıştır. Üzerine $400 \mu \mathrm{l}$ AP1 buffer ve $4 \mu \mathrm{l}$ RNase A ilave edilerek $65^{\circ} \mathrm{C}$ 'de 10 dk kuru blok isiticida inkübasyona bırakılmıştır. Bu inkubasyon periyodundan sonra tüpün içerisine $130 \mu \mathrm{AP} 2$ buffer ilave edilip, karıştırılmış ve $5 \mathrm{dk}$ buzda inkübe edildikten sonra $14.000 \mathrm{rpm}$ 'de $5 \mathrm{dk}$ santrifüj edilmiştir. 2 ml'lik toplama tüpüne pembe kolonlar (QIAshredder spin colon) yeleştirilmiş ve karışım kolona aktarılıp 14.000 rpm'de 2 dk santrifüj edilmiştir. Diğer toplama tüpüne beyaz kolon (DNeasy Mini spin colon) yerleştirilmiş ve kolona yaklaşık $650 \mu \mathrm{l}$ olan sıvı transfer edilerek 15 dakika beklenmiş ve 8.000 rpm'de $1 \mathrm{dk}$ süreyle santrifüj edilmiştir. Beyaz kolon (DNeasy Mini spin colon) yeni bir toplama tüpüne aktarılmış ve üzerine $500 \mu \mathrm{l} \mathrm{AW}$ bufferdan ilave edilerek $14.000 \mathrm{rpm}$ 'de $1 \mathrm{dk}$ santrifüj edilmiş ve tüpte toplanan sıvı uzaklaştırılmıştır. Tüpe $100 \mu \mathrm{l} \mathrm{AE}$ buffer ilave edilmiş ve $5 \mathrm{dk}$ oda sıcaklığında inkübasyona bırakıldıktan sonra $8.000 \mathrm{rpm}$ 'de $1 \mathrm{dk}$ santrifüj edilmiş ve ependorf içinde toplanan $100 \mu \mathrm{l}$ DNA solüsyonu, testler yapılıncaya kadar $-20^{\circ} \mathrm{C}$ 'de muhafaza edilmiştir.

\subsubsection{PCR koşulları}

İzolasyon çalışmalarında elde edilen DNA'lar Çizelge 1'de yer alan literatürlerde belirtilen Actin, $\beta$-tubulin, ITS ve LSU gen bölgelerine ait primerler dizilimleri ile PCR yöntemi kullanılarak çoğaltılmıştır. PCR ürünleri, etidyum bromid ile boyanmış \%1.2'lik agaroz jel içerisinde ayrılmış ve UV ışığı altında görüntülenmiştir. PCR uygulaması için total mix hacmi $50 \mu 1$ olacak şekilde hazırlanmış ve termocycler cihazında PCR koşulları; $94{ }^{\circ} \mathrm{C}$ ' de $3 \mathrm{dk}$ (denatürasyon), $94{ }^{\circ} \mathrm{C}$ ' de $30 \mathrm{sn}, 50-60{ }^{\circ} \mathrm{C}$ 'de 45 sn, $72{ }^{\circ} \mathrm{C}$ 'de $60 \mathrm{sn}$ toplam 40 döngü ve $72^{\circ} \mathrm{C}^{\prime}$ de $10 \mathrm{dk}$ olacak şeklinde gerçekleştirilmiştir.

Çizelge 1. Primer çiftleri

\begin{tabular}{|c|c|c|c|c|}
\hline Genin Ad 1 & $\begin{array}{l}\text { Primerin } \\
\text { Ad1 }\end{array}$ & Primer Dizilimi & $\begin{array}{l}\text { Beklenen } \\
\text { Boyut }\end{array}$ & Literatür \\
\hline \multirow{2}{*}{ Actin geni } & ActF & 5'-CGTCTT CCGTAAGTCTCCCC-3' & \multirow{2}{*}{$210-220$ bp } & \multirow{2}{*}{ Tang ve ark.,2012 } \\
\hline & ActR & 5'-TACGAGTCCTTC TGGCCCAT-3' & & \\
\hline \multirow{2}{*}{$\begin{array}{l}\beta \text {-tubulin } \\
\text { geni }\end{array}$} & Bt2a & 5'-GGTAAC CAAATCGGTGCTGCTTTC-3' & \multirow{2}{*}{ 410-420 bp } & \multirow{2}{*}{$\begin{array}{l}\text { Glass ve Donaldson, } \\
1995\end{array}$} \\
\hline & Bt2b & 5'-ACCCTCAGTGTAGTGACCCTTGGC-3' & & \\
\hline \multirow{2}{*}{ ITS } & ITS-4 & 5'-TCCTCCGCTTATTGATATGC-3' & \multirow{2}{*}{700 bp } & White ve ark., 1990 \\
\hline & ITS-6 & 5’-GAAGGTGAAGTCGTAACAAGG-3’ & & Cooke ve ark., 2000 \\
\hline \multirow{2}{*}{ LSU } & NL1 & 5'-GCATATCAATAAGCGGAGGAAAAG-3' & \multirow{2}{*}{ 600-700 bp } & \multirow{2}{*}{ O’Donnell, 1993} \\
\hline & NL4 & 5'-GGTCCGTGTTTCAAGACGG-3' & & \\
\hline
\end{tabular}

\section{Bulgular}

Antepfıstığında salkım ve sürgün yanıklık hastalığının yaygınlık oranı (\%) ve hastalık şiddetini belirlemek amaciyla Mersin, Gaziantep ve Kilis ve illerinde 2015 ve 2016 yıllarında periyodik olmayan aralıklarla toplam 254 survey çalışması yapılmıştır.

2015 yılı antepfıstığı salkım ve sürgün yanıklık hastalığının tespiti için survey yapılan alanlara ait bilgiler Çizelge 2'de verilmektedir. 
Çizelge 2. 2015 yılına ait antepfıstığı salkım ve sürgün yanıklık hastalığı survey alanları

\begin{tabular}{|c|c|c|c|}
\hline Survey Tarihi & \multicolumn{3}{|c|}{ Survey Alanları } \\
\hline & İl & İlçe & Mahalle \\
\hline 30.03.2015 & Mersin & Silifke & Senir, İmambekirli, Gökbelen \\
\hline 27.04.2015 & Kilis & Merkez & İnanlı, Arpakesmez, Öncüpınar \\
\hline 26.05 .2015 & Gaziantep & Nizip & $\begin{array}{l}\text { Yağmuralan, Cinfelekü, Karacahöyük } \\
\text { Gökçeli }\end{array}$ \\
\hline 09.06.2015 & Mersin & Silifke & Senir, İmambekirli, Gökbelen \\
\hline 17.06.2015 & Kilis & Elbeyli & Merkez \\
\hline 08.07.2015 & Gaziantep & Oğuzeli & $\begin{array}{c}\text { Merkez, Yeşildere, Yakacık, Tuzluca, Güveçli Yeşildere, } \\
\text { Güzeloba }\end{array}$ \\
\hline 14.07.2015 & Gaziantep & Nizip & $\begin{array}{l}\text { Turlu, Battal, Kıvırcık, Soylu, Akçaköy, Subağı, Yeşerti, } \\
\text { Yolağzı, Gevence, Karacaburun, Das hüyük }\end{array}$ \\
\hline 27.07.2015 & Gaziantep & Oğuzeli & Yalnızbağ, Kayacık, Güzeloba, Uğurova, \\
\hline 04.08.2015 & Gaziantep & Oğuzeli & $\begin{array}{c}\text { Yakacık, Acar, Tunazade, Anam Hacı Çiftliği, Tuzluca, } \\
\text { Doğanpınar }\end{array}$ \\
\hline 10.08.2017 & Gaziantep & Nizip & Düzbayır, Kovanlı, Gökçeli, Dokuzlu, Doğanpınar \\
\hline 12.08.2015 & Gaziantep & Kargamış & Merkez, Kıvırcık, Akçaköy, Düzbayır \\
\hline 19.08.2015 & Gaziantep & Oğuzeli, Kargamış & Merkez, Taşlı, Çiftlik köy, Akça köy, Alacalı \\
\hline 09.09.2015 & Gaziantep & Yavuzeli, Araban & Küçük Karakuyu, Gökçepayam, Akkoç, Yaylacık, \\
\hline
\end{tabular}

Antepfıstığ1 bahçelerindeki salkım ve sürgün yanıklık hastalığının 2015 yılına ait ilk enfeksiyonu salkımlarda 09.06.2015 tarihinde Mersin ili Silifke ilçesi Senir mahallesinde tespit edilmiștir.

2016 yılı antepfıstığı salkım ve sürgün yanıklık hastalığının tespiti için survey yapılan alanlara ait bilgiler de Çizelge 3'de verilmektedir.

Çizelge 3. 2016 yılına ait antepfıstığı salkım ve sürgün yanıklık hastalığı survey alanları

\begin{tabular}{|c|c|c|c|}
\hline \multirow[t]{2}{*}{ Survey Tarihi } & \multicolumn{3}{|r|}{ Survey Alanları } \\
\hline & İl & İlçe & Mahalle \\
\hline 24.04.2016 & Mersin & Silifke & Senir, İmambekirli, Gökbelen \\
\hline 05.05.2016 & Mersin & Silifke & Senir, İmambekirli, Gökbelen \\
\hline 18.05.2016 & Mersin & Silifke & Senir, İmambekirli, Gökbelen \\
\hline 31.05.2016 & Mersin & Silifke & Senir, İmambekirli, Gökbelen \\
\hline 07.06.2016 & Mersin & Silifke & Senir, İmambekirli, Gökbelen \\
\hline 09.06.2016 & Gaziantep & Nizip & $\begin{array}{c}\text { Turlu, Battal, Kıvırcık, Soylu, Akçaköy, Subağı, Yeşerti, } \\
\text { Yolağzı, Gevence, Karacaburun, Das hüyük, Turlu köyü, Kıraklı, } \\
\text { Battal köyü, Bozbağ }\end{array}$ \\
\hline 13.06.2016 & Gaziantep & Oğuzeli, Yavuzeli & $\begin{array}{l}\text { Yalnızbağ, Kayacık, Güzeloba, Uğurova, Merkez, Taşlı, Çiftlik } \\
\text { köy, Akça köy, Alacalı, Küçük Karakuyu, Gökçepayam, Akkoç, } \\
\text { Yaylacık }\end{array}$ \\
\hline 21.06.2016 & Mersin & Silifke, Mut & Senir, İmambekirli, Gökbelen, Alahanlı \\
\hline 18.07.2016 & Mersin & Silifke & Senir, İmambekirli, Gökbelen \\
\hline 20.07.2016 & Gaziantep & Nizip, Karkamış & $\begin{array}{l}\text { Merkez, Düzbayır, Kovanlı, Gökçeli, Dokuzlu, Yağmuralan, } \\
\text { Karacahöyük, Gökçeli Doğanpınar, Dokuzlu, Mercanlı, Soylu, } \\
\text { Subağı, Türkyurdu, Öncüler, Yolağzı köyü }\end{array}$ \\
\hline 26.07.2016 & Mersin & Silifke & Senir, İmambekirli, Gökbelen \\
\hline 28.07.2016 & Kilis & Merkez, Elbeyli & $\begin{array}{c}\text { Öncüpınarı, Kulecik, ,Zeytinli, Yavuzlu, Beylerbeyi, Akıncı, } \\
\text { Dölek, Bozcayazı, Havuzluçay, Alahan, Çangallı }\end{array}$ \\
\hline 01.08.2016 & Mersin & Silifke & Senir, İmambekirli, Gökbelen \\
\hline 16.08.2016 & Mersin & Mut & Alahanl, Nuru \\
\hline 19.08.2016 & Gaziantep & Oğuzeli, Elbeyli & $\begin{array}{l}\text { Merkez, Çengelli köyü, Yakacık, Acar, Anam Hacı Çiftliği, } \\
\text { Tuzluca, Doğanpınar, Çapılcakı, Yeşildere }\end{array}$ \\
\hline
\end{tabular}

Antepfıstığı bahçelerindeki salkım ve sürgün yanıklık hastalığının 2016 yılına ait ilk enfeksiyonu salkımlarda 31.05.2016 tarihinde yine Mersin ili Silifke ilçesi Senir mahallesinde tespit edilmiştir.

2015 ve 2016 yıllarında antepfistığı bahçelerinin bulunduğu il ve ilçelerde incelenen bahçe sayısı, bulaşık bahçe sayısı, yaygınlık oranı (\%) ve hastalık şiddetine ait bilgiler Çizelge 4 ve 5'de verilmiştir.

2015 y1lında Mersin, Gaziantep ve Kilis illerinde survey yapılan 206 antepfıstı $\breve{g}$ bahçesinden 48 'inin salkım ve sürgün yanıklık hastalığı ile bulaşık olduğu belirlenmiştir (Çizelge 4). 
Çizelge 4. Mersin, Gaziantep ve Kilis il ve ilçelerinde antepfıstı̆̆ı salkım ve sürgün yanıklık hastalığının 2015 yılına ait yaygınlık oranı (\%) ve hastalık şiddeti değerleri

\begin{tabular}{|c|c|c|c|c|c|}
\hline \multicolumn{2}{|c|}{ Bahçelerin bulunduğu } & \multirow{2}{*}{$\begin{array}{l}\text { İncelenen Bahçe } \\
\text { Sayıs1 }\end{array}$} & \multirow{2}{*}{$\begin{array}{c}\text { Bulaşık Bahçe } \\
\text { Sayısı }\end{array}$} & \multirow{2}{*}{$\begin{array}{c}\text { Yaygınlık Oranı } \\
\text { (\%) }\end{array}$} & \multirow[t]{2}{*}{ Hastalık Şiddeti } \\
\hline İl & İlçe & & & & \\
\hline Mersin & Silifke & 27 & 25 & 92.59 & 4.2 \\
\hline \multirow[t]{5}{*}{ Gaziantep } & Araban & 15 & 1 & 5.00 & 1.2 \\
\hline & Kargamış & 21 & 3 & 14.28 & 1.6 \\
\hline & Nizip & 47 & 11 & 23.40 & 2.2 \\
\hline & Oğuzeli & 30 & 5 & 16.66 & 1.9 \\
\hline & Yavuzeli & 28 & 0 & 0.00 & - \\
\hline \multirow[t]{2}{*}{ Kilis } & Merkez & 25 & 3 & 12.00 & - \\
\hline & Elbeyli & 13 & 0 & 0.00 & - \\
\hline \multicolumn{2}{|c|}{ Toplam Bahçe sayısı } & 206 & 48 & - & - \\
\hline
\end{tabular}

Salkım ve sürgün yanıklık hastalığının 2015 yılı surveyinde; bulaşık bahçe sayısı en fazla olan il Mersin’dir. Bu ildeki yaygınlık oranı \%92.59 ve hastalık şiddeti ise 4.2'dir. Gaziantep ilinin Araban, Kargamış, Nizip ve Oğuzeli ilçelerinde bulunan antepfıstığı bahçelerinde salkım ve sürgün yanıklık hastalı̆̆ 1 tespit edilirken, Yavuzeli ilçesinde hastalık tespit edilmemiştir. Kilis ilinde de hastalık tespit edilmemiştir. 2015 yılında survey yapılan Mersin, Gaziantep ve Kilis illerinde incelenen toplam 206 antepfıstığı bahçesinin \% 23.3’ü salkım ve sürgün yanıklık hastalığı ile bulaşıtır.

2016 yılında Mersin, Gaziantep ve Kilis illerinde survey yapılan 254 antepfistığı bahçesinden 91'inin salkım ve sürgün yanıklık hastalığı ile bulaşık olduğu belirlenmiştir (Çizelge 5).

Çizelge 5. Mersin, Gaziantep ve Kilis il ve ilçelerinde antepfıstığı salkım ve sürgün yanıklık hastalığının 2016 yılına ait yaygınlık oranı (\%) ve hastalık şiddeti değerleri

\begin{tabular}{|c|c|c|c|c|c|}
\hline \multicolumn{2}{|c|}{ Bahçelerin bulunduğu } & \multirow{2}{*}{$\begin{array}{c}\text { İncelenen Bahçe } \\
\text { Sayis1 }\end{array}$} & \multirow[t]{2}{*}{ Bulaşık Bahçe Sayısı } & \multirow{2}{*}{$\begin{array}{c}\text { Yaygınlık Oranı } \\
(\%)\end{array}$} & \multirow[t]{2}{*}{ Hastalık Şiddeti } \\
\hline İl & İlçe & & & & \\
\hline \multirow[t]{3}{*}{ Mersin } & Silifke & 37 & 31 & 83.78 & 3.1 \\
\hline & Mut & 15 & 8 & 53.33 & 2.4 \\
\hline & Gülnar & 15 & 3 & 20.00 & 1.9 \\
\hline \multirow[t]{5}{*}{ Gaziantep } & Merkez & 8 & 2 & 25.00 & 1.5 \\
\hline & Karkamış & 11 & 3 & 27.27 & 1.2 \\
\hline & Nizip & 45 & 14 & 31.11 & 1.9 \\
\hline & Oğuzeli & 41 & 11 & 26.82 & 1.7 \\
\hline & Yavuzeli & 7 & 0 & 00.00 & - \\
\hline \multirow[t]{2}{*}{ Kilis } & Merkez & 30 & 9 & 30.00 & 1.8 \\
\hline & Elbeyli & 45 & 10 & 28.88 & 1.7 \\
\hline Toplam Bahçe & & 254 & 91 & - & - \\
\hline
\end{tabular}

2016 yılı salkım ve sürgün yanıklık hastalığı surveyinde; Mersin ili yaygınlık oranı \% 83.78 ile \% 20.00, hastalık şiddeti ise 3.1 ile 1.9 arasındadır. Gaziantep ili Merkez ilçede hastalığın varlığı belirlenirken, Yavuzeli ilçesinde ise yine hastalık tespit edilmemiştir. Kilis ili Merkez ve Elbeyli ilçelerinde hastalığın varlığı belirlenmiştir. 2016 yılında survey yapılan Mersin, Gaziantep ve Kilis illerinde incelenen toplam 254 antepfistığı bahçesinin \%35.8'inin hastalıkla bulaşık olduğu saptanmıştır.

Her iki yılda yapılan survey çalışmalarında toplam 460 antepfıstığı bahçesinin 139'unun salkım ve sürgün yanıklık hastalığı ile bulaşık olduğu belirlenmiştir. İncelenen bahçeler içerisinde toplam bulaşık bahçe sayısı ile ortalama yaygınlık oranı (\%) ve ortalama hastalık şiddeti Akdeniz Bölgesinde daha yüksek olmuştur (Çizelge 6). 
Çizelge 6. Mersin, Gaziantep ve Kilis illerine ait survey yapılan iki yıla ait toplam incelenen ve bulaşı bulunan bahçe sayıları ile iki yılın ortalamasını içeren antepfıstığı salkım ve sürgün yanıklık hastalığı yaygınlık oranı (\%) ve hastalık şiddeti değerleri

\begin{tabular}{lcccc}
\hline \multicolumn{1}{c}{ İl } & $\begin{array}{c}\text { İncelenen Toplam Bahçe } \\
\text { Sayıs }\end{array}$ & $\begin{array}{c}\text { Toplam Bulaşı Bahçe } \\
\text { Sayı1 }\end{array}$ & $\begin{array}{c}\text { Ortalama Yaygınlı Oranı } \\
(\%)\end{array}$ & $\begin{array}{c}\text { Ortalama Hastalık } \\
\text { Şiddeti }\end{array}$ \\
\hline Mersin & 94 & 67 & 71.28 & 2.90 \\
Gaziantep & 253 & 50 & 19.76 & 1.32 \\
Kilis & 113 & 22 & 19.47 & 1.73 \\
\hline Toplam & 460 & 139 & - & - \\
\hline
\end{tabular}

Survey esnasında antepfıstığı bahçelerinde hastalık belirtisi gösteren örneklerden yapılan izolasyon sonucu hastalık etmenine ait 25 izolat makroskobik (koloninin rengi, pigment oluşumu ve gelişme hızı vb.) ve mikroskobik (hif özellikleri, spor oluşumu, sporların şekli, rengi, büyüklüğü vb.) özelliklerine göre cins düzeyinde Botryosphaeria spp. olarak tanılanmış ve patojenisite çalışması sonucu illere göre ortalama hastalık şiddeti değerleri belirlenmiştir (Çizelge 7).

Çizelge 7. Antepfıstığı salkım ve sürgünlerinden elde edilen Botryosphaeria spp. izotlarının elde edildiği il, sayı ve ortalama hastalık şiddeti değerleri

\begin{tabular}{cccc}
\hline İl & İzolat Adı & İzolat Sayıs & Ortalama Hastalık Şiddeti \\
\hline Mersin & Botryosphaeria spp. & 19 & 1.8 \\
Gaziantep & Botryosphaeria spp. & 5 & 1.3 \\
Kilis & Botryosphaeria spp. & 1 & 1.6 \\
\hline
\end{tabular}

İzolasyonu yapılan ve morfolojik özelliklerine göre Botryosphaeria spp. olarak tanımlanan izolatlara ait koloniler başlangıçta beyaz renkte iken zamanla zeytin yeşilinden siyaha dönüşmüştür. Yaklaşık üç hafta PDA besi ortamında gelişen kültürlerin yüzeyinde siyah renkli piknitler oluşmuştur. Piknitlerden oluşan konidiosporların ise renksiz, bölmesiz, bir hücreli ve 18-27 X 4-7 $\mu \mathrm{m}$ ebatlarında olduğu tespit edilmiştir (Şekil 1).

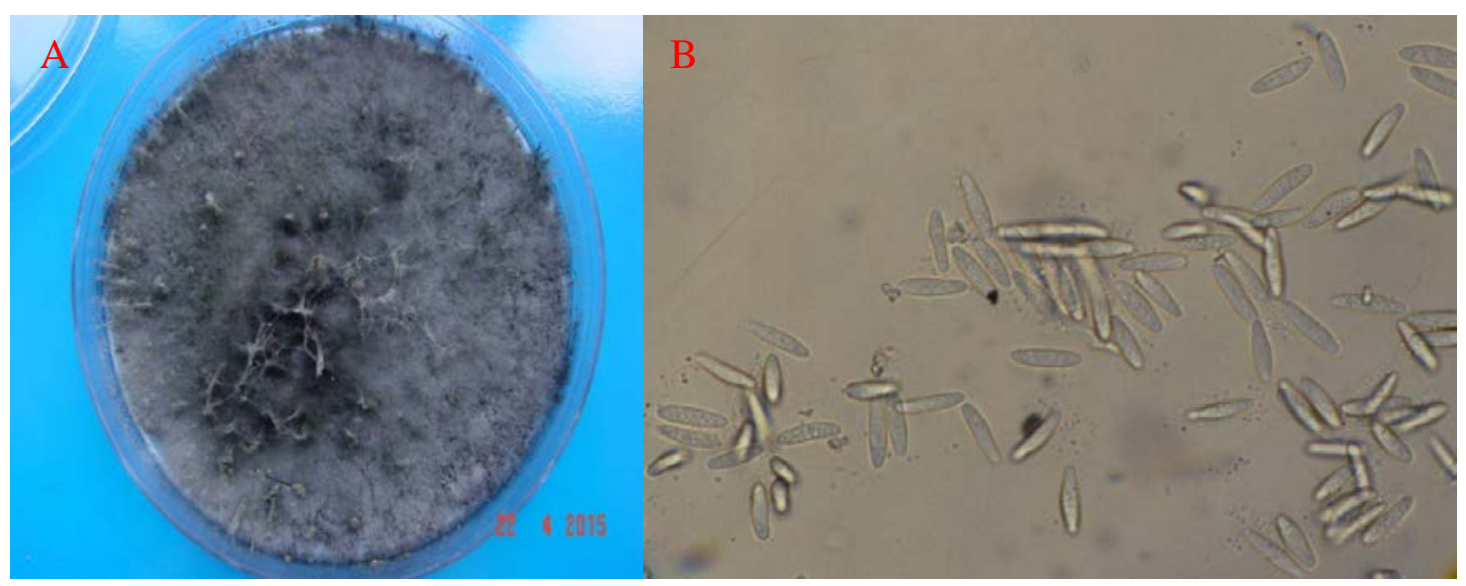

Şekil 1. Botryosphaeria sp.’nin koloni gelişimi (A) ve konidiosporları (B).

Patojenisite çalışmalarında kullanılan 25 adet Botryosphaeria spp. izolatı püskürtme yöntemi ile meyve üzerine inokule edilmiş ve 1 hafta sonra meyveler üzerinde yanıklık şeklinde tipik hastalık belirtilerinin doğal koşullarda rastlanılan hastalık belirtileri ile aynı olduğu belirlenmiştir. (Şekil 2). 


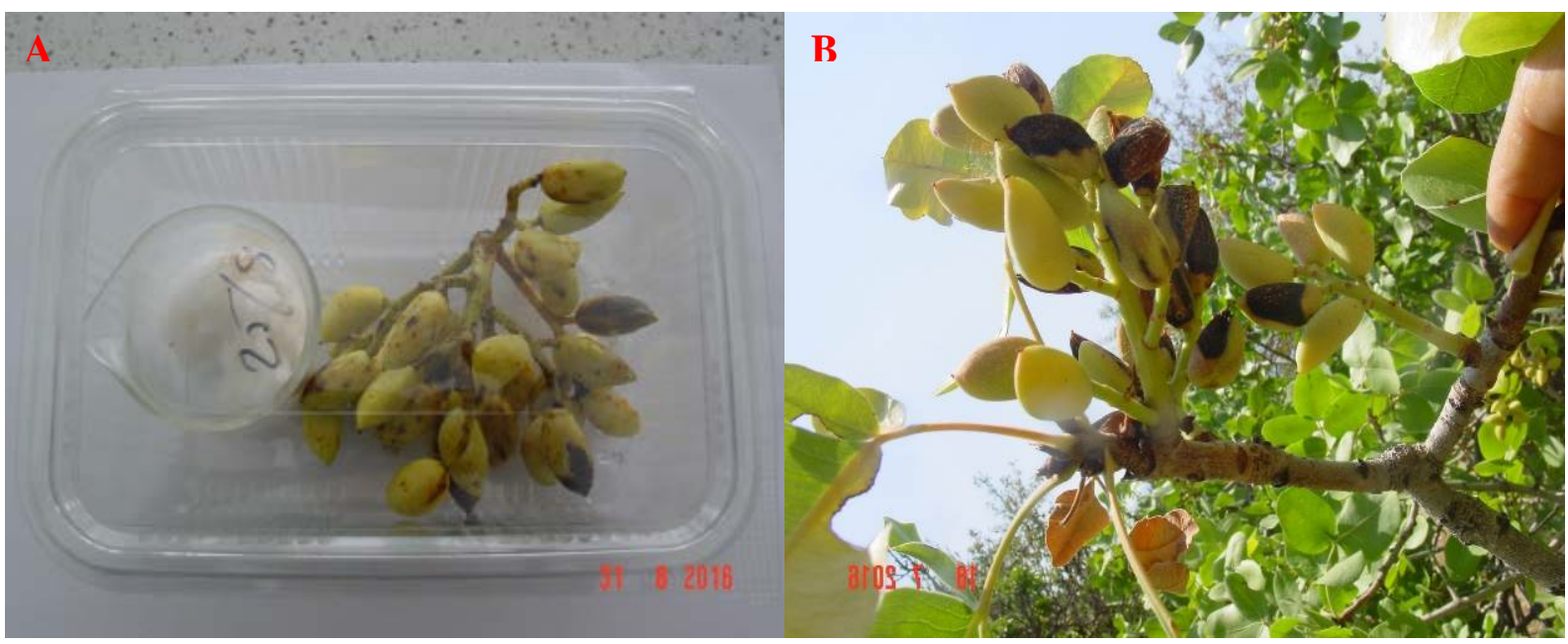

Şekil 2. Botryosphaeria spp.'nin kontrollü şartlarda (A) ve doğal koşullarda (B) meyvede oluşturduğu hastalık belirtisi.

Morfolojik olarak tanısı ile patojenisite çalışması yapılan ve Botryosphaeria spp. olduğu belirlenen izolatlar içinden 58-59 nolu Silifke izolatları Actin, $\beta$-tubulin, ITS ve LSU gen bölgelerinin hepsinde bant vermiş (Şekil 3, 4, 5 ve 6) ve sekansa gönderilerek NCBI veri tabanına kaydedilmiştir.

Actin gen bölgesi için yapılan PCR çalışmaları sonucunda 210-220 bp civarında bantlar gözlemlenmiştir (Şekil 3).

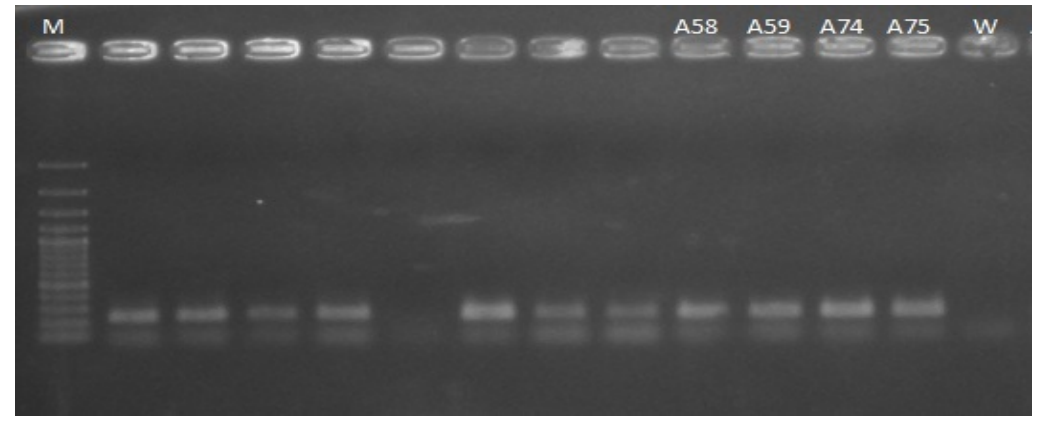

Şekil 3. 58 ve 59 nolu izolatın PCR analizlerinin Actin gen bölgesi sonuçları.

$\beta$-tubulin gen bölgesi için yapılan PCR çalışmaları sonucunda 410-420 bp civarında bantlar gözlenmiştir (Şekil 4).

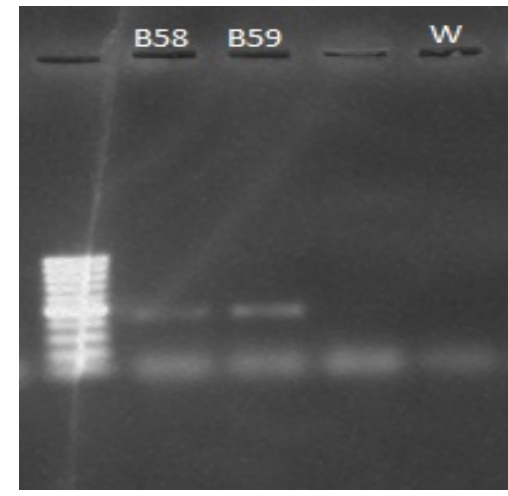

Şekil 4. 58 ve 59 nolu izolatın PCR analizlerinin $\beta$-tubulin gen bölgesi sonuçları.

ITS gen bölgesi için yapılan PCR çalışmaları sonucunda 700 bp civarında bantlar gözlenmiştir. NCBI BLAST analizleri sonucunda 58-59 nolu izolatın B. dothidea olduğu belirlenmiştir (Şekil 5). 


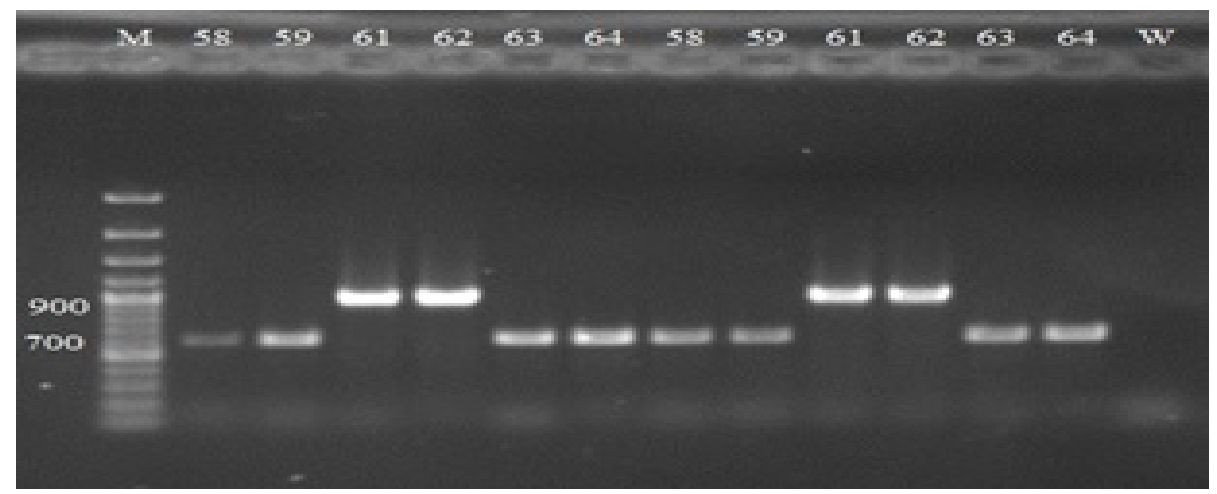

Şekil 5. 58 ve 59 nolu izolatın PCR analizlerinin ITS gen bölgesi sonuçları.

LSU gen bölgesi için yapılan PCR çalışmaları sonucunda 600-700 bp civarında bantlar gözlenmiştir. NCBI BLAST analizleri sonucunda 58-59 nolu izolatın B. dothidea olduğu belirlenmiştir (Şekil 6).

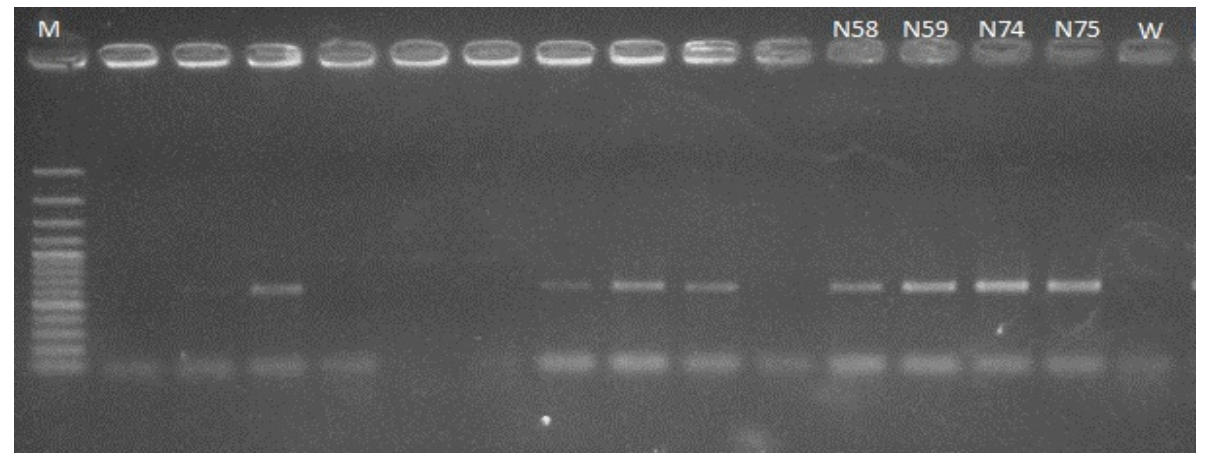

Şekil 6. 58 ve 59 nolu izolatın PCR analizlerinin LSU gen bölgesi sonuçları.

Bd 58 ve Bd 59 numaralı izolatların nükleotid dizileri NCBI gen bankasına ITS gen bölgesi için MN809578 ve MN809581 ve LSU gen bölge için de MN809583 ve MN809585 erişim numaraları ile kaydedilmiş ve NCBI Gen bankasında Botryosphaeria-ID veritabanında depolanan ve B. dothidea olarak tanımlanan KU163447 ve KU163448 izolatları ile \%100 eşleşmiştir.

\section{Tartışma ve Sonuç}

Antepfistığında salkım ve sürgün yanıklık hastalığının yaygınlığı (\%) ve şiddetini belirlemek amacıyla 2015 ve 2016 yıllarında yapılan survey çalışmalarında; Mersin, Gaziantep ve Kilis illerinde bulunan 460 bahçeden 139'unun salkım ve sürgün yanıklık hastalığı ile bulaşı olduğu belirlenmiştir. Survey çalışmalarında bulaşık olarak belirlenen bahçelerin \%48'i Mersin ili, \%36'sı Gaziantep ili ve \%16'sı ise Kilis ili üretim alanındadır. Ortalama yaygınlık oranları, Mersin ilinde \%71.28, Gaziantep ilinde \%19.76 ve Kilis ilinde \%19.47'dir. Ortalama hastalık şiddeti ise Mersin ilinde 2.90, Gaziantep ilinde 1.32 ve Kilis ilinde 1.73'dür. Bu sonuçlara göre toplam bulaşık bahçeye sayısı içindeki bulaşık bahçe oranı (\%), yaygınlık oranı (\%) ve hastalık şiddeti en yüksek olan Mersin ilidir. Gaziantep ilinin yaygınlı oranı (\%) Kilis iline göre yüksek olmasına karşın hastalık şiddeti değeri Kilis ilinden düşüktür. Mersin ili antepfıstığı üretim alanlarında karazenk hastalık etmeni Pseudocercospora pistacina sorun oluşturmaması nedeniyle belirli bir proğram dahilinde fungusit uygulaması yapılmamaktadır. Aynı zamanda salkım sürgün yanıklık hastalığı nedeniyle kuruyan ve enfeksiyon kaynağı olan bitki parçalarının imhasına da özen gösterilmemektedir. Bu iki sebep hastalı̆̆ın yaygınlığ 1 ve şiddetinin artmasının ana faktörleridir. Buna karşın Gaziantep ve Kilis illerinde önemli bir sorunu olan karazenk hastalığı ile mücadelede uygulanan bitki koruma ürünleri ve mücadele programı (Anonim, 2016) aynı zamanda salkım ve sürgün yanıklık hastalığının yaygınlık oranı (\%) ve hastalık şiddetini düşürmektedir. Salkım sürgün yanıklık hastalığı etmeni B. dothidea'nın, birçok 
bitki türünü hastalandırabilen havai kökenli bir fungus olması (Teviotdale ve ark., 2002), bitki dokularında primer inokulum kaynağı olarak oluşturduğu piknitlerden salınan konidiosporların altı yıl canlılığını sürüdürebilmesi (Ahimera ve ark., 2003) tespit edilen sonuçlar ile örtüşmekte ve desteklemektedir. Patojenisite çalışmasında inokulasyon sonrası meyveler üzerinde tipik yanıklık şeklinde belirtiler tespit edilmiş ve bu belirtiler doğal koşullarda tespit edilen simptomlar ile benzerlik göstermiştir. Milholland (1972) B. dothidea izolatı ile yaptı̆̆ 1 patojeniste çalışmasında inokulasyondan 1 hafta sonra meyveler üzerinde yanıklık şeklinde tipik hastalık belirtileri oluştuğunu tespit etmiştir. Michailides ve Morgan (2004) salkım ve sürgün yanıklığı hastalığının doğal koşullarda meyvelerde yanıklık şeklinde belirtiler gösterdiğini bildirmiştir. Bu çalışmaların sonuçları, belirlenen simptomlar ile benzerdir. İzole edilen kültürlerin morfolojik olarak cins düzeyinde tanısında kullanılan kültür rengi, piknit oluşumu, konidiosporun morfolojik özellikleri, Slippers ve ark. (2004) tarafından yapılan tanımlama ile benzerlik göstermiştir. Moleküler olarak taranan ITS ve LSU gen bölgelerine ait BLAST analizi sonucu salkım ve sürgün yanıklık hastalığı etmeninin $B$. dothidea olduğu belirlenmiştir.

Sonuç olarak; Botryosphaeriaceae familyası funguslarından olan B. dothidea tek veya çok yıllık geniş bir konukçu dizisine sahiptir. Kozmopolit bir dağılıma sahip olan bu familyaya ait türler firsatçı, sekonder veya latent patojenler olarak tanınmakta ve meyvede, sürgünde ve gövdede enfeksiyon yapabilmektedir. Akdeniz ve Güneydoğu Anadolu bölgesinde yaygınlığg (\%) ve şiddeti belirlenen salkım ve sürgün yanıklığı hastalığının mücadelesine yönelik çalışmalara ihtiyaç bulunmaktadir.

\section{Kaynakça}

Ahimera, N., Driever, G. F., \& Michailides, T. J. (2003). Relationships Among Propagule Numbers of Botryosphaeria dothidea, Latent Infections, and Severity of Panicle and Shoot Blight in Pistachio Orchards. Plant Disease, Vol. 87, No. 7, 846-853.

Anonim. (1997). Descriptors for Pistachio (Pistacia vera L.). International Plant Genetic Resources Institute, Rome, Italy. 53 p.

Anonim. (2009). Pistachio Panicle and Shoot Blight. UC IPM: Pest Management Guidelines: Pistachio, UC ANR Publication 3461.

Anonim. (2016). Antepfıstı̆̆ Hastalık ve Zararlıları İle Mücadele. www.tarim.gov.tr / TAGEM / Belgeler / yayin/ 010. (Erişim Tarihi: 12.06.2020).

Anonim. (2018a). Antepfistığı Yetiştiriciliği. Ankara Üniversitesi. https:// acikders.ankara.edu.tr /mod/resource/view.php?id=3889. (Erişim Tarihi: 12.06.2020).

Anonim. (2018b). Faostat. www.fao.org/faostat. (Erişim Tarihi: 12.06.2020).

Camele, I., Marcone, C., \& Cristinzio, G. (2005) Detection and identification of Phytophthora species in Southern Italy by RFLP and sequence analysis of PCR amplified nuclear ribosomal DNA. Eur. J. Plant Pathol. 11, 1-14.

Cooke, D.E.L., Drenth, A., Duncan, J.M., Wagels, G., \& Brasier, C.M. (2000). A molecular phylogeny of Phytophthora and related Oomycetes. Fungal Genetics and Biology, 30, 17-32.

Erkı1ıç, A., Canıhoş, Y., Biçici, M., Pala, H., \& Canıhoş, E. (1999). Çukurova'da Mineola Tangelolarda Alternaria Kahverengi Leke (Alternaria alternata f.sp. citri) Hastalığının Şiddetinin Belirlenmesi. Tr. J. of Agriculture and Forestry. 23 (1999). Ek Say1 3, 643-647.

Glass N.L., \& Donaldson, G.C. (1995). Development of primer sets designed for use with the PCR to amplify conserved genes from filamentous ascomycetes. Appl Environ Microbiol. 61(4), 132330.

Horsfall, J. F., \& Barratt, R. W. (1945). An improved grading system for measuring plant disease. (Abstr.) Phytopathology, 35, 655.

Karman, M. (1971). Denemelerin Kuruluşu ve Değerlendirme Esasları. Tarım bakanlığ Zirai Mücadele ve Zirai Karantina Genel Müdürlügü Yayınları, Mesleki Kitaplar Serisi, Ankara, 269 s.

Leonard G., \& Ashley W. (2011). Fungicides Required for Blight Prevention in Pistachios.U.S. Pesticide Benefits Case Study No. 9, May 2011.

Michailides, T.J., \& Morgan D.P. (2004). Panicle and Shoot Blight of Pistachio: A Major Threat to the California Pistachio Industry. APS net.org. Available at: http://www.apsnet.org/ online /feature/pistachio/pistachio.pdf. 
Milholland, R. D. (1972). Histopathology and Pathogenicity of Botryosphaeria dothidea on Blueberry Stems. Phytopathology. Vol, 62, 654 pp.

O’Donnell, K. (1993). Fusarium and Its Near Relatives. In: Reynolds, D.R., Taylor, J.W. (Eds.), The Fungal Holomorph: Mitotic, Meiotic, and Pleomorphic Speciation in Fungal Systematics. CAB International, Wallingford, pp. 225-233.

Slippers B., Crous, P.W., Denman, S., \& Coutinho, T.( 2004). Combined Multiple Gene Genealogies and Phenotypic Characters Differentiate Several Species Previously Identified as Botryosphaeria dothidea. Mycologia, 96(1), 83-101.

Tang, W., Ding, Z., Zhou, Z.Q., Wang, Y.Z., \& Guo, L. Y. (2012). Phylogenetic and Pathogenic Analyses Show That the Causal Agent of Apple Ring Rot in China Is Botryosphaeria dothidea. Plant Disease. 96(4), 486-496.

Tekin, H., Arpacı, S., Atl1, H.S., Açar, İ., Karadağ, S., Yükçeken, Y., \& Yaman, A. (2001). Antepfistı̆̆ Yetiştiriciliği. Yayın No: 13: 65-66. Antepfıstığı Araştırma Enstitüsü, Gaziantep.

Teviotdale, B.L., Michailides, T.J., \& Pscheidt, J. W. (2002). Compendium of Nut Crop Diseases in Temperate Zones. The American Phytopathological Society. 89 pp.

White, T.J., Bruns, T., Lee, S., \& Taylor, J. (1990). Amplification and Direct Sequencing of Fungal Ribosomal RNA Genes for Phylogenetics. Academic Press, New York. B., 1971. Dematiaceous Hyphomycetes. CMI, Kew,Surrey.

Zhang, M., Wu, H.Y., \& Geng, Y. H. (2012). First Report of Fusicoccum aesculi Causing Leaf Spots of Paconia suffruticosa in Hen. Plant Disease. Vol, 96, Num; 11. 